\author{
분말 합금법으로 제조된 $\mathrm{Ni}-\mathrm{Cr}-\mathrm{Al}$ 초합금 다공체의 \\ 인장 특성에 미치는 변형률 속도 및 하중 방향 효과 \\ 김규식 ${ }^{1} \cdot$ 배정석 $^{2} \cdot$ 오재성 ${ }^{3} \cdot$ 이기안 $^{1 *}$ \\ 1인하대학교 신소재공학과 \\ ${ }^{2}$ (주)알란텀 \\ 3조선내화(주)
}

\title{
Effect of Strain Rate and Loading Direction on the Mechanical Properties of Ni-Cr-Al Superalloy Foam Fabricated by Powder Alloying Method
}

\author{
Kyu-Sik Kim ${ }^{1}$, Jung-Suk $\mathrm{Bae}^{2}$, Jae-Sung $\mathrm{Oh}^{3}$, and Kee-Ahn Lee ${ }^{1, *}$ \\ ${ }^{1}$ Department of Materials Science and Engineering, Inha University, Incheon 22212, Republic of Korea \\ ${ }^{2}$ Alantum Corp., Seongnam 13229, Republic of Korea \\ ${ }^{3}$ Chosun Refractories Co. Ltd., Pohang 37862, Republic of Korea
}

\begin{abstract}
The powder-alloyed metallic sheet foam manufacturing process has the advantage of being able to control pore shape, size, and distribution more easily and homogeneously than conventional foam manufacturing processes. The effects of strain rate and tensile direction on the mechanical properties of $\mathrm{Ni}$ $\mathrm{Cr}-\mathrm{Al}$ superalloy foam fabricated by powder alloying method were investigated. As a result of structural characteristics obtained by X-ray tomography and scanning electron microscopy, average pore sizes were measured to be $2762.4 \mu \mathrm{m}$ (normal direction), $2709.1 \mu \mathrm{m}$ (rolling direction, RD), and $2518.4 \mu \mathrm{m}$ (transverse direction, TD) respectively. The $\mathrm{Y}-\mathrm{Ni}$ matrix and $\mathrm{Y}^{\prime}-\mathrm{Ni}_{3} \mathrm{Al}$ (which was evenly distributed in the strut) were identified as the main constituent phases of the $\mathrm{Ni}-\mathrm{Cr}-\mathrm{Al}$ foam used in this study. Tensile tests were conducted with strain rates of $10^{-2} \sim 10^{-4} \mathrm{~s}^{-1}$ along the rolling and transverse directions. The results showed that the tensile strength in the RD direction was $1.84 \sim 2.01 \mathrm{MPa}$, and in the TD direction was 1.2 1.27 MPa. The elongation in the TD direction was higher (30 36\%) than in the RD direction (17 22\%). It is noteworthy that the effect of quasi-static strain rate on the tensile strength and elongation was negligible. However, the loading direction was found to change mechanical properties significantly. This study also discussed the deformation behavior of the $\mathrm{Ni}-\mathrm{Cr}-\mathrm{Al}$ superalloy foam through observations of the fracture surface, and realtime observations during tensile tests in different directions.
\end{abstract}

(Received February 5, 2020; Accepted May 14, 2020)

Keywords: Ni-Cr-Al superalloy foam, structural characteristics, microstructure, tensile properties, strain rate

\section{1. 서 론}

개기공 다공체(Open-cell foam)는 넓은 표면적, 낮은 열 용량, 높은 에너지 흡수 능력, 그리고 액체 또는 기체 투 과성이 뛰어난 소재로 알려져 있다 [1]. 그 중에서도 $\mathrm{Ni}$ 계 초합금 다공체는 고온 특성이 우수한 것으로 보고되고 있

- 김규식: 박사과정, 배정석·오재성: 연구원, 이기안: 교수

${ }^{*}$ Corresponding Author: Kee-Ahn Lee

[Tel: +82-32-860-7532, E-mail: keeahn@inha.ac.kr]

Copyright (C) The Korean Institute of Metals and Materials
어 방열 부품, 진동 감쇠 재료, 고온용 필터 그리고 화학 촉매 산업의 담체 등 넓은 적용 분야에서 적용이 기대되고 있다 [2-5].

$\mathrm{Ni}-\mathrm{Cr}-\mathrm{Al}$ 계 합금 다공체는 $\mathrm{Ni}$ 계 다공체 중에서도 현재까 지 가장 많은 연구가 진행된 소재이다. $\mathrm{Ni}$ 합금 다공체는 다양한 공정을 통하여 제조될 수 있으며[6-17], 상온 기계 적 특성 [14-15], 고온 기계적 특성 [18], 산화 특성 [19] 등의 물성이 보고된 바 있다. H. Choe와 D.C. Dunand에 따르면 $\mathrm{Ni}-\mathrm{Al}$ 그리고 $\mathrm{Ni}-\mathrm{Cr}-\mathrm{Al}$ 다공체의 상온 압축 및 고 온 크립 거동은 strut의 압축 또는 굽힘(bending) 거동에 
기인하는 것으로 제시한 바 있다 [13]. 또한 본 연구진들 은 Ni-Fe-Cr-Al 다공체의 고온 압축 크립 거동에 미치는 기공 크기 효과에 대하여 제시하였으며, 기공의 크기가 감 소됨에 따라 다공체의 상대밀도가 증가되고 크립 변형 저 항성이 증가할 수 있다고 보고하였다 [18]. 이와 같이 $\mathrm{Ni}$ 계 다공체의 기계적 특성은 실제 부품으로 적용하기 위해 중요하게 인식되고 있으나, 대부분의 연구는 압축 기계적 거동에 대해 수행되어 왔다. 반면 $\mathrm{Al}$ 다공체의 경우, 대표 적인 경량 충격 흡수체, 그리고 구조용 소재로 적용이 기 대되고 있음에 따라 인장 특성, 그리고 변형률 속도 영향 에 대한 연구가 활발히 진행되고 있다 [20-21]. 즉, $\mathrm{Ni}$ ㄱ ᅨ 다공체 또한 충격 흡수체 또는 기계적 특성을 요구하는 구 조용 소재로 적용되기 위하여 인장 특성, 그리고 변형률 속도에 따른 기계적 거동이 함께 연구되어야 한다. 그러나 현재까지도 $\mathrm{Ni}$ 계 초합금 다공체의 인장 특성, 변형률 속도 영향, 인장 시험 방향에 따른 기계적 특성 변화 또는 변형 거동을 연구한 결과는 부족한 실정이다.

본 연구에서는 분합 합금법을 이용하여 Ni-Cr-Al 다공체 를 제조하고, 이 소재의 상온 인장 특성에 미치는 준정적 변형률 속도 및 인장 방향의 영향에 대해 조사하였다. 그 리고 기계적 특성을 다공체의 구조적 및 미세조직학적 특 징과 연계하여 해석하고자 하였으며 변형 거동, 그리고 기 계적 특성이 변화하는 원인에 대하여 고찰해보았다.

\section{2. 실험 방법}

본 연구에서는 (주)알란텀에서 분말 합금화 공정[22]으로 제조된 $\mathrm{Ni}$ 계 초합금 다공체 사용하였다. 방향에 따라 다른 기공 크기를 가지는 약 $4.8 \mathrm{~mm}$ 두께의 개기공(open porous) 폴리머 다공체 표면에 순수 $\mathrm{Ni}$ 을 도금하였으며, 이 후 폴리머 다공체를 제거하는 열처리를 수행하여 순수 $\mathrm{Ni}$ 다공체를 제조하였다. 제조된 $\mathrm{Ni}$ 다공체에 바인더(binder) 와 목표 조성을 계산하여 정량의 합금 분말을 도포하였다. 그리고 디바인딩 (de-binding) 및 전이 액체상 소결 (transient liquid phase sintering) 열처리를 통하여 최종적 으로 $\mathrm{Ni}-10.7 \% \mathrm{Cr}-3.4 \% \mathrm{Al}(\mathrm{wt} \%)$ 조성의 초합금 다공체를 제조하였다.

$\mathrm{Ni}-\mathrm{Cr}-\mathrm{Al}$ 합금 다공체의 기공 구조와 지주(strut) 표면 형태를 주사 전자 현미경 (scanning electron microscopy, $\mathrm{SEM}$, TESCAN, VEGA II)으로 관찰하였으며, 이미지 분 석 프로그램을 이용하여 평균 기공 크기(average pore size), strut 두께, strut 벽면 두께를 측정했다. 이와 함께 Micro-CT (Skyscan 1172 high-resolution micro-CT)를 (a)

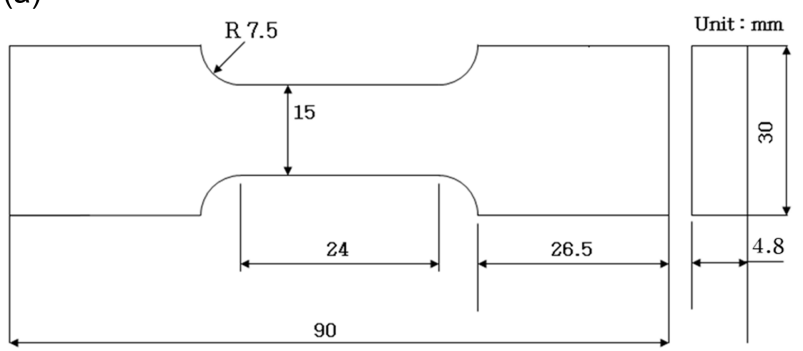

(b)

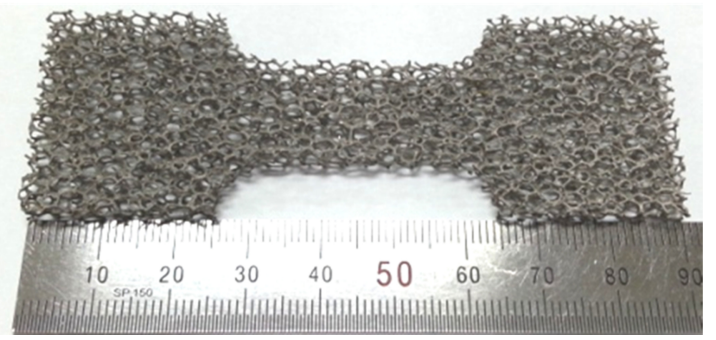

Fig. 1. (a) Size and morphology of the tensile specimen, and (b) Ni$\mathrm{Cr}-\mathrm{Al}$ tensile specimen used in this study.

이용하여 다공체의 구조적 인자, 그리고 상대밀도를 정량 화 하였다. 추가적으로 상대밀도를 확인하기 위하여 다공 체 크기를 제어하여 방전가공으로 재가공하였다. 다공체의 두께와 길이, 너비를 측정하여 겉보기 부피를 계산하였으 며, 다공체의 무게를 측정하여 겉보기 밀도를 측정했다. 이 후 다공체 밀도를 bulk Ni-Cr-Al 소재의 밀도로 나눠주어 최종 상대밀도를 계산했다. Ni-Cr-Al 금속 다공체의 상 분 석을 위하여 X-선 회절(X-ray diffraction, $\mathrm{XRD}$, RIGAKU D2000) 분석을 수행하였다. 다공체의 미세조직 확인을 위하여 $\mathrm{SiC}$ 연마지를 이용하여 연마하였으며, 최종 적으로 $1 \mu \mathrm{m}$ 수준의 $\mathrm{Al}_{2} \mathrm{O}_{3}$ 슬러리를 이용하여 미세 연마 를 수행하였다. 이후 $85 \mathrm{ml} \mathrm{H} \mathrm{H}_{2} \mathrm{O}+10 \mathrm{ml} \mathrm{H}_{2} \mathrm{NO}_{3}+5 \mathrm{ml}$ glacial acetic acid 용액으로 $5 \mathrm{~V}$, 수 초간 에칭하였고, 주 사 전자 현미경 (Jeol, JSM-6700F)으로 관찰하였다.

인장 실험은 그림 1 에서 나타낸 것과 같이 $\mathrm{Ni}-\mathrm{Cr}-\mathrm{Al}$ 다 공체를 방전가공으로 재가공하여 사용하였다. 방향에 따른 기 계적 특성을 확인하기 위하여 $\mathrm{RD}$ 방향과 $\mathrm{TD}$ 방향을 인장 축으로 하는 시험편을 각각 제작하였다. 인장 시험편은 $15 \mathrm{~mm}(\mathrm{~W}) \times 4.8 \mathrm{~mm}(\mathrm{~T}) \times 24 \mathrm{~mm}(\mathrm{~L})$ 크기의 표점을 가 지는 dog-bone 형태로 가공되었다. 인장 시험은 INSTRON 8801 장비로 초기 변형률 속도를 $10^{-4} / \mathrm{s}, 10^{-3} / \mathrm{s}$, 그리고 $10^{-2} / \mathrm{s}$ 로 각각 3 번 이상 수행하여 Ni-Cr-Al 다공체의 대표 적인 인장 특성을 도출했다. 인장 시험 동안 다공체의 변 형 거동을 확인하기 위하여 디지털 카메라를 이용하여 변 형량에 따른 다공체의 형태 변화를 실시간으로 관찰하였다. 

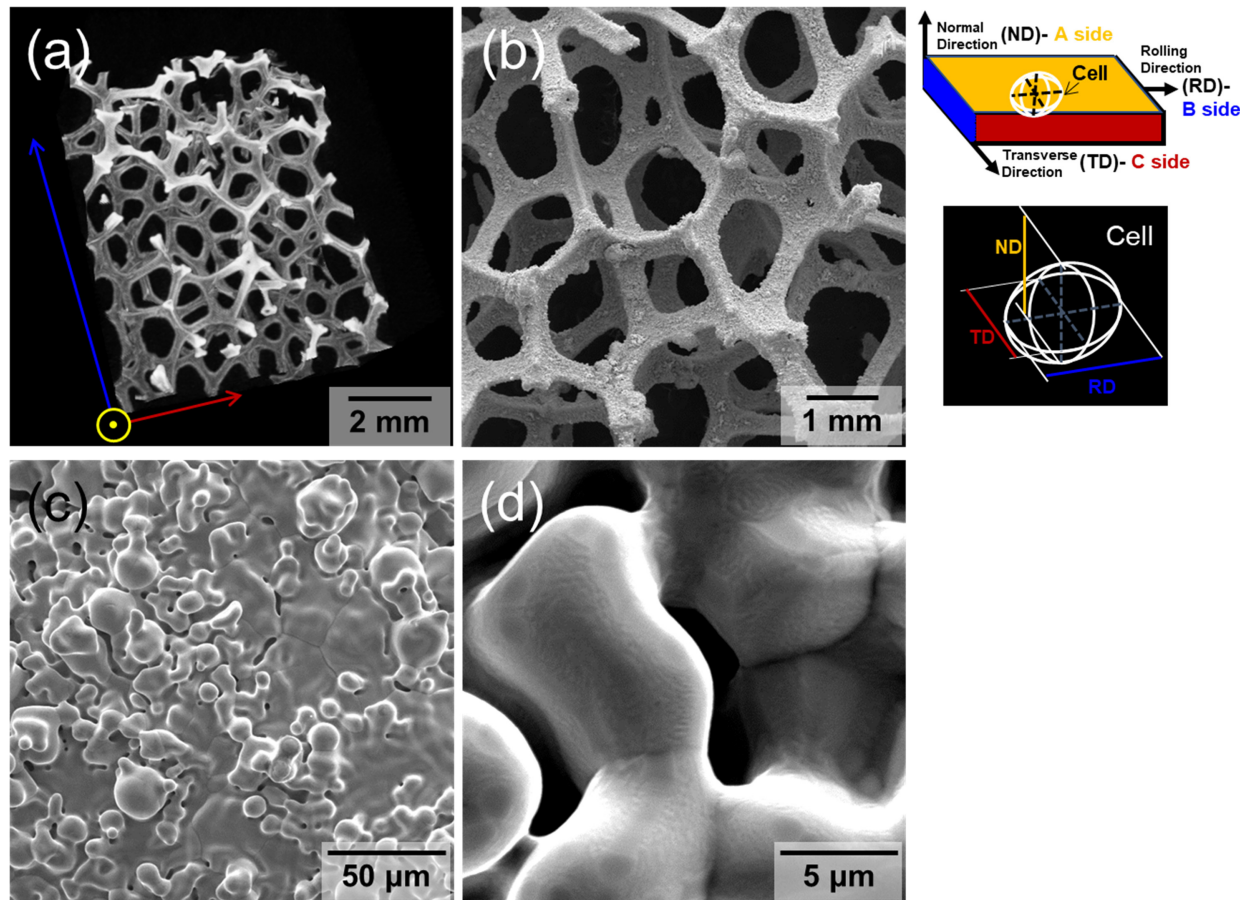

Fig. 2. (a-b) Structural characteristics and (c-d) surface morphology of the Ni-Cr-Al superalloy foam.

또한 인장 시험 후, 인장 변형 및 파괴 거동을 알아보기 위 해 변형 후 시편의 구조를 주사 전자 현미경 (TESCAN, VEGA II)으로 관찰하였다.

\section{3. 결과 및 고찰}

\subsection{Ni-Cr-Al 다공체의 구조 및 미세조직학적 특징}

그림 2에서는 본 연구에서 사용한 $\mathrm{Ni}-\mathrm{Cr}-\mathrm{Al}$ 다공체의 구조 및 표면을 X-ray 단층 촬영 및 $\mathrm{SEM}$ 을 이용하여 관 찰한 결과를 도시하였다. $\mathrm{Ni}-\mathrm{Cr}-\mathrm{Al}$ 다공체는 12 면체 (dodecahedron)와 14면체 (tetrakaidecahedron)가 혼재된 Weaire-Phelan bubble 형태로 구성되어 있었다. 평균 기공 크기의 경우, 관찰 방향에 따라서 다소 차이를 나타냈으며 그 값은 각각 $2762.4 \mu \mathrm{m}(\mathrm{ND}), 2709.1 \mu \mathrm{m}(\mathrm{RD})$, 그리고 $2518.4 \mu \mathrm{m}(\mathrm{TD})$ 로 측정되었다. 기공 크기 차이는 제조 공 정에서 사용된 폴리우레탄 다공체 구조에 기인하는 것으로 생각된다. Strut는 삼각형 파이프 형태로 관찰되었으며, 평 균 두께는 $341.0 \mu \mathrm{m}$, 평균 cell 벽면 두께는 $27.6 \mu \mathrm{m}$ 로 측정되었다. 또한 $\mathrm{Ni}-\mathrm{Cr}-\mathrm{Al}$ 다공체의 기공도(porosity)는 $97.07 \%$, 상대 밀도(relative density)는 $2.93 \%$ 으로 얻어졌 다. 그림 2 (b)에서 나타낸 것과 같이 strut의 표면에서는 합금 다공체 제조를 위한 합금 분말이 부착되어 있는 형태 를 보여주고 있으며 표면에 균일하게 도포되어 있었다. 이
를 더 높은 배율로 확인(그림 2 (c))을 하면 소결에 의해 도포된 입자들이 strut에 잘 결합되어 것을 알 수 있었다. 그리고 strut 부분과 합금 분말이 소결됨에 따라서 초기 분 말의 형상(구형)을 유지하지 못하고 반구형 나타나고 있으 며, 표면에 많은 요철을 형성하고 있었다. 분말과 분말 사이 에서도 소결되어 소결목(sintered neck)이 형성되어 있었다. 이 형태는 다공체의 표면적(surface area)을 효과적으로 증가 시킬 수 있는 특징으로 판단된다. 즉, 단층 촬영 결과에서 측정된 것과 같이 $0.91 \mathrm{~m}^{2} / \mathrm{L}$ 의 높은 표면적을 나타낸다.

Strut 단면에서 관찰한 미세조직학적 특징을 그림 3에서 나타내었다. 그 결과, 초기 분말 위치, strut의 내부에서 측 정한 조성 (EDS point 분석 결과)은 매우 유사한 값으로 나타났으며, $\mathrm{Ni}, \mathrm{Cr}$, 그리고 $\mathrm{Al}$ 합금 원소가 균일하게 분 포되어 있는 결과를 얻을 수 있었다. 다공체의 경우 기공 이 포함되어 있어 $\mathrm{XRF}$ 를 이용한 성분 분석 결과 $(\mathrm{Ni}-$ $10.7 \% \mathrm{Cr}-3.4 \% \mathrm{Al}$ )와 $\mathrm{EDS}$ point 성분 분석에서 차이가 발 생하는 것으로 판단된다. 기존 다공체 제조 공정 중 본 연 구에서 사용한 공정과 가장 유사한 pack-cementation 공정 [13-14]과 비교할 경우, 본 연구에서 적용한 공정은 다음과 같은 장점이 있을 것으로 예상된다. Pack-cementation 공 정의 경우, 합금화 온도 및 시간이 변화함에 따라서 다공 체의 합금 조성이 위치에 따라 크게 변화할 수 있다. 이러 한 현상은 각 합금 원소의 확산 속도가 다른 것에 기인하 

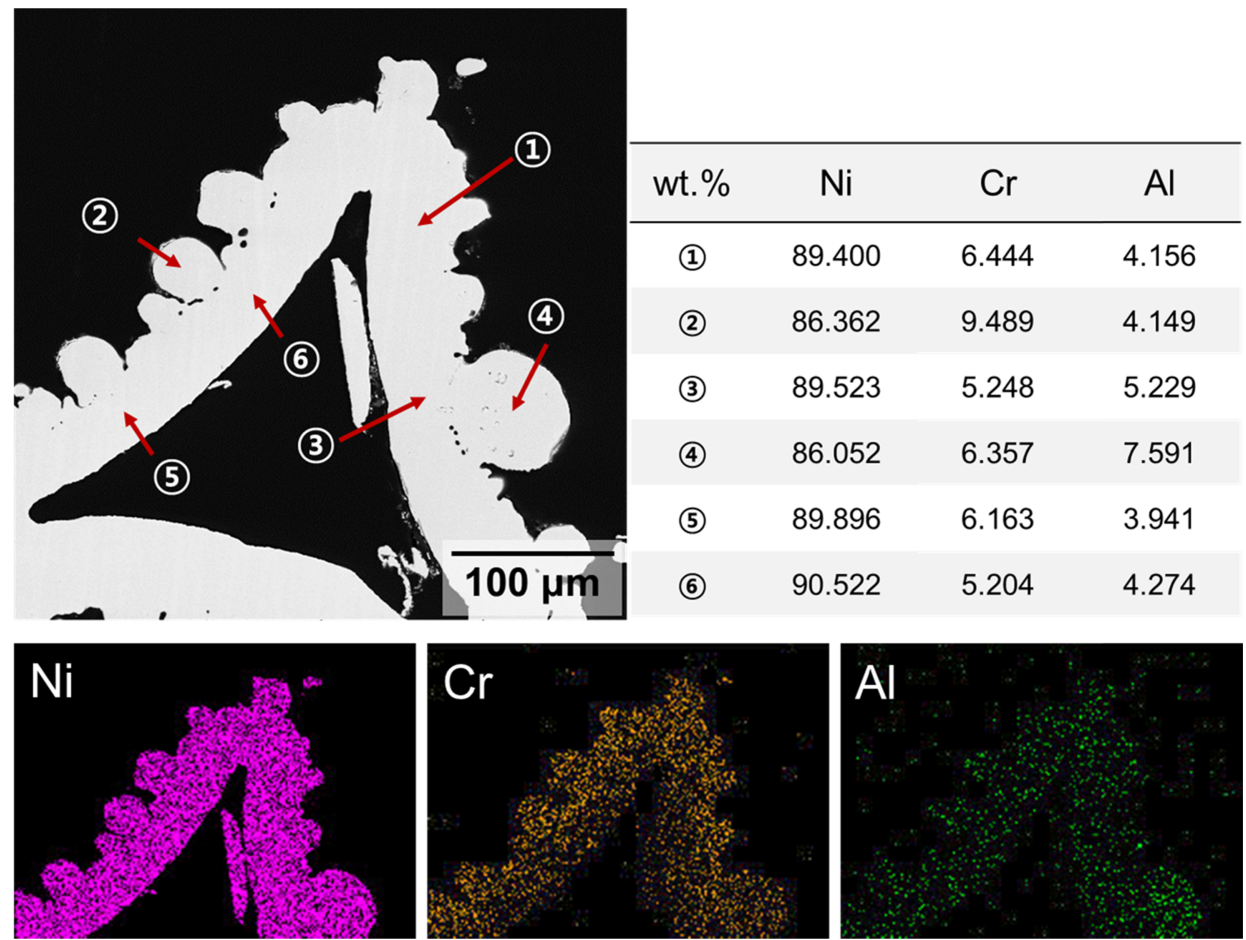

Fig. 3. Cross-sectional image of the strut in the Ni-Cr-Al superalloy foam and distribution of alloying elements by EDS and EDS mapping.

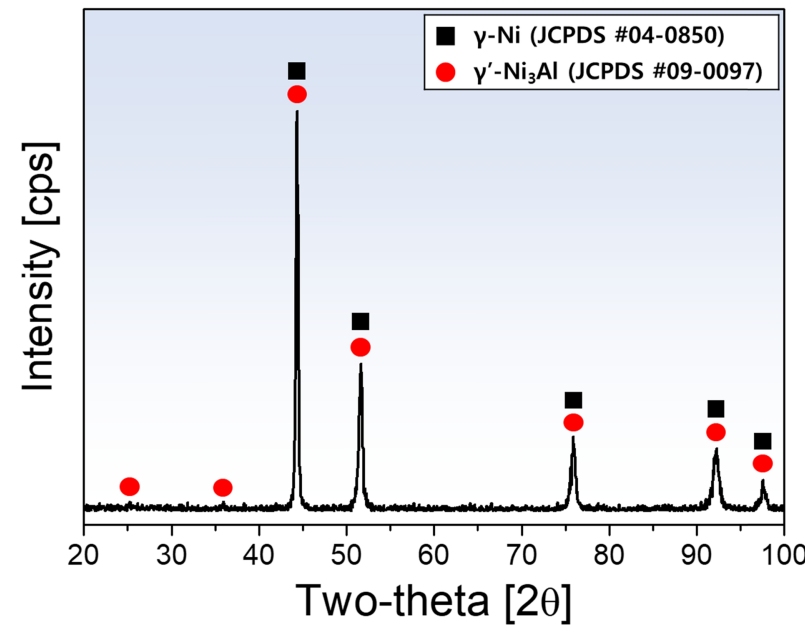

Fig. 4. Result of X-ray diffraction analysis.

며 결과적으로 다공체 조성을 정확하게 제어하기 난해하다 는 단점이 있다. 반면 본 연구에서 사용한 분말 합금법은 합금 분말의 분무량(spray amount, $\mathrm{kg} / \mathrm{m}^{2}$ )을 제어하여 다 공체의 최종 조성을 결정할 수 있다. 즉, 합금 분말 분무 량이 결정되면 최종 합금 조성은 결정되며 확산에 따른 균 일도에만 영향을 받는다. 합금 조성의 균일한 제어를 통하 여 미세조직에서도 매우 균일한 조직을 얻을 수 있어서 다

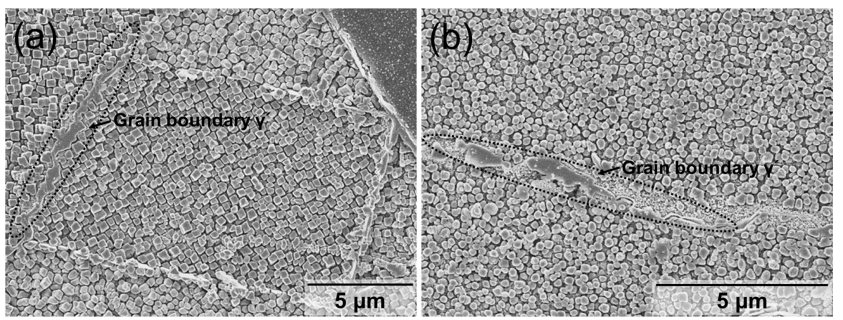

Fig. 5. Representative microstructures of the strut in the Ni-Cr-Al foam; (a) surface region and (b) interior of a strut.

공체의 기계적, 화학적 특성 제어가 상대적으로 용이할 것 으로 사료된다.

합금 원소의 균일한 제어는 미세조직 제어에서도 장점을 가질 수 있다. 그림 4 에서는 본 연구에서 사용한 Ni-Cr$\mathrm{Al}$ 다공체의 $\mathrm{XRD}$ 상 분석 결과를 나타내었다. 그 결과, $\mathrm{Ni}$ 계 합금에서 일반적으로 나타나는 $\mathrm{Ni}$ 기지 (JCPDS card \#04-0850)와 $\gamma^{\prime}$ (JCPDS card \#09-0097)로 구성되어 있었다. 그림 5에서는 strut 표면부 (a), 그리고 strut의 내 부 미세조직을 (b)에서 각각 나타내었다. 그림에서 나타난 것과 같이 위치에 관계없이 매우 유사한 특징을 보이고 있 다. 구형 또는 육면체의 석출물이 strut 내부에 균일하게 분포하고 있는 것을 확인할 수 있으며, 결정립계(그림 5 점선)에서는 판상의 $\gamma^{\prime}$ 이 관찰되었다. 그림 3 에서 측정된 
(a)

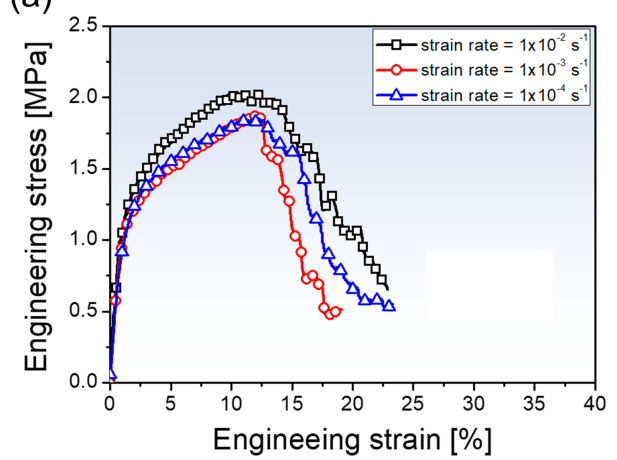

(b)

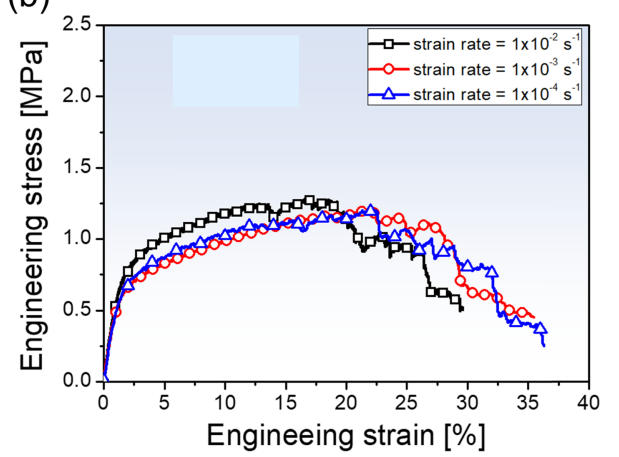

Fig. 6. Tensile stress-strain curves according to the range of quasi-static strain rates, and tensile direction; (a) RD direction and (b) TD direction.

것과 같이 $\mathrm{Al}$ 함량이 상대적으로 높고 $\mathrm{Cr}$ 함량이 낮게 측 정되는 이유는 $\gamma^{\prime}$ 에 기인하는 것으로 판단된다. $\gamma^{\prime}$ 의 분율 은 $60.7 \%$, 결정립내에 존재하는 $\gamma^{\prime}$ 크기는 약 200 $500 \mathrm{~nm}$ 의 분포를 가지는 것으로 측정되었으며, 결정립계에 서는 상대적으로 큰 $2 \sim 5 \mu \mathrm{m}$ 크기의 $\gamma^{\prime}$ 이 관찰되었다.

\section{$3.2 \mathrm{Ni}-\mathrm{Cr}-\mathrm{Al}$ 다공체의 상온 인장 특성에 미치는 변 형률 속도 및 방향의 영향}

그림 6에서는 변형률 속도, 그리고 인장 방향에 따른 $\mathrm{Ni}-\mathrm{Cr}-\mathrm{Al}$ 다공체의 응력-변형률 곡선을 나타내었다. $\mathrm{RD}$ 방 향으로 인장 시험을 수행한 경우 (그림 6 (a)), 변형률 속 도에 따라서 $1.07 \mathrm{MPa}\left(10^{-2} / \mathrm{s}\right), 0.94 \mathrm{MPa}\left(10^{-3} / \mathrm{s}\right)$, 그리 고 $0.84 \mathrm{MPa}\left(10^{-3} / \mathrm{s}\right)$ 의 항복강도를 가지는 것으로 측정되 었다. 인장 강도의 경우에도 $2.01 \mathrm{MPa}\left(10^{-2} / \mathrm{s}\right), 1.87$ $\mathrm{MPa}\left(10^{-3} / \mathrm{s}\right), 1.84 \mathrm{MPa}\left(10^{-4} / \mathrm{s}\right)$ 로 측정됨에 따라서 변형 률 속도가 증가함에 따라서 유사하거나 다소 높은 강도를 나타내었다. 그러나 연신율은 강도와는 다르게 변형률 속 도에 따른 특별한 경향성이 없는 것으로 확인되었으며, 그 값은 약 $17 \sim 22 \%$ 의 범위로 얻어졌다. TD 방향의 항복강도 는 각각 $0.65 \mathrm{MPa}\left(10^{-2} / \mathrm{s}\right), 0.54 \mathrm{MPa}\left(10^{-3} / \mathrm{s}\right), 0.52 \mathrm{MPa}$ $\left(10^{-4} / \mathrm{s}\right)$ 로 측정되었으며, 인장 강도는 $1.27 \mathrm{MPa}\left(10^{-2} / \mathrm{s}\right)$, $1.20 \mathrm{MPa}\left(10^{-3} / \mathrm{s}\right)$, 그리고 $1.20 \mathrm{MPa}\left(10^{-4} / \mathrm{s}\right)$, 연신율은 약 30 36\%의 범위를 가지는 것으로 확인되었다. TD 방 향은 $\mathrm{RD}$ 방향의 인장 강도보다 전체적으로 낮은 값을 나 타냈고 상대적으로 높은 연신율을 나타냈다. 이 결과를 통 하여 준정적 변형률 영역에서는 변형률 속도가 증가함에 따라서 강도는 다소 증가하는 경향이 나타났고 연신율은 두 방향에서 모두 특별한 경향성이 관찰되지 않았다.

그림 7에서는 인장 시험 후 파면을 관찰한 후, 대표적인 결과를 나타냈다. 그림 7 (a-b)는 $\mathrm{RD}$ 방향, 변형률 속도
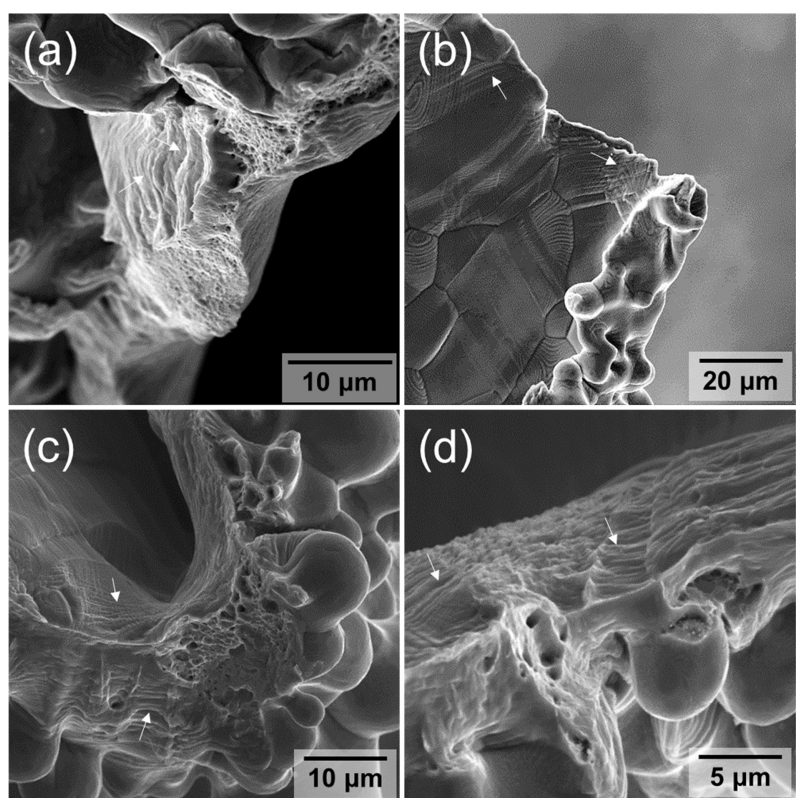

Fig. 7. Tensile fractured surfaces of the Ni-Cr-Al superalloy foam with a strain rate of (a-b) $10^{-2} \mathrm{~s}^{-1}$ and (c-d) $10^{-4} \mathrm{~s}^{-1}$.

$10^{-2} / \mathrm{s}$ 조건으로 수행된 $\mathrm{Ni}-\mathrm{Cr}-\mathrm{Al}$ 다공체의 인장 파면으로 전형적인 연성 파괴 형태인 dimple이 주로 관찰되었다. 또 한 파면의 주위를 확인해 보면 slip band (흰색 화살표)가 크게 형성되어 있었으며, 입계 파괴 보다는 입내 파괴가 주로 발생하였다. 이 결과를 통하여 그림 5 에서 언급했던 결정립계에 존재하는 $\gamma^{\prime}$ 이 Ni-Cr-Al 다공체의 연신율을 감 소시키는 영향은 낮을 것으로 예상할 수 있었다. 또한 변 형률 속도가 $10^{-4} / \mathrm{s}$ 로 감소하더라도 유사한 형태의 dimple 형태와 파면 주변부에서 slip band가 동일하게 관찰되었다 (그림 7 (c-d)). 즉, 본 연구에서 적용한 준정적 변형률 속 도 변화는 Ni-Cr-Al 다공체의 강도 변화, 연신율의 변화, 

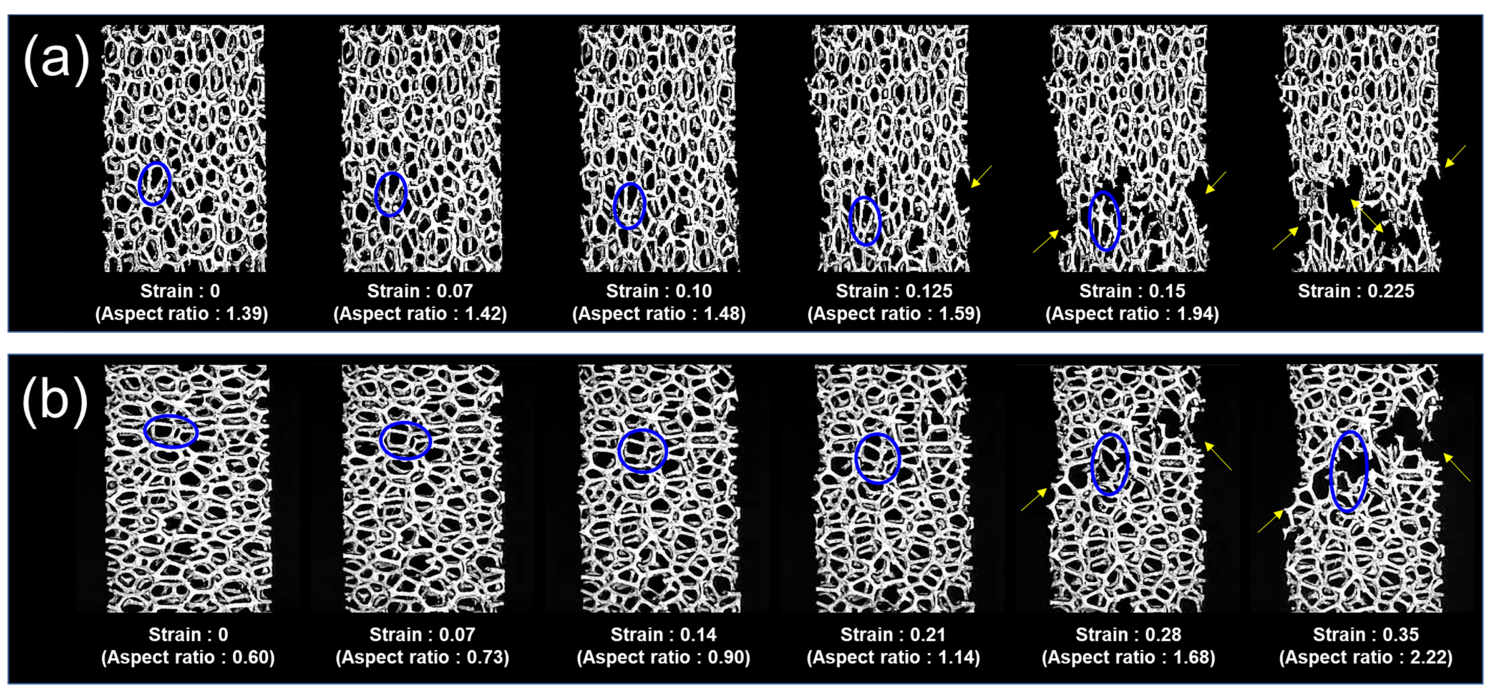

Fig. 8. Plastic deformation behavior of the Ni-Cr-Al superalloy foam according to the tensile strain; (a) RD direction and (b) TD direction. Blue circles (region of interest) used as a representative pore during tensile deformation and yellow arrows show macroscopic shear directions.

그리고 파괴 거동에 모두 큰 영향이 없는 것으로 나타났다.

\section{$3.3 \mathrm{Ni}-\mathrm{Cr}-\mathrm{Al}$ 다공체의 방향에 따른 변형 거동}

일반적으로 다공체의 강도, 그 중에서 항복 강도 또는 plateau 강도는 다공체의 상대 밀도와 상관 관계가 있는 것으로 알려져 있으며 아래의 수식으로 표현된다 [1].

$$
\frac{\sigma_{y}^{*}}{\sigma_{y}}=0.3\left(\frac{\rho^{*}}{\rho_{s}}\right)^{1.5}
$$

여기에서 $\sigma_{y}^{*}$ 는 다공체의 항복 강도, $\sigma_{y}$ 벌크 소재의 항 복 강도, 그리고 $\left(\rho^{*} / \rho_{s}\right)$ 는 상대 밀도를 의미한다. 본 연 구에서 사용한 $\mathrm{Ni}-\mathrm{Cr}-\mathrm{Al}$ 합금의 상대 밀도는 $2.93 \%$ 로 측 정되었으며 이 값은 측정 방향에 영향을 받지 않는다. 상 기의 수식은 기공의 크기가 방향에 따라서 동일(구형)하다 는 가정을 하고 있어 기존의 관계를 이용하면 본 연구에서 나타나는 인장 시험 방향에 따른 기계적 특성의 차이를 설 명할 수가 없다.

$\mathrm{Ni}-\mathrm{Cr}-\mathrm{Al}$ 다공체의 구조, 그리고 인장 시험의 방향을 고 려하여 방향에 따른 강도 차이를 해석하고자 인장 시험 동 안 변형률에 따른 구조체(기공 형태, strut)의 변화를 확인 하였으며 그 결과를 그림 8에 도시하였다. 가장 대표적인 차이는 그림 2에서 다공체의 구조적 특징에서 언급된 것 과 같이 타원형의 기공 형태를 가지고 있어 인장 방향에 따라 기공의 장축 배열 관계가 다르게 나타나는 점이다. $\mathrm{RD}$ 방향으로 인장 시험을 하는 경우에 기공의 장축 $(\mathrm{RD}$ 방 향)과 인장 시험 방향이 평행한 반면 $\mathrm{TD}$ 방향으로 인장
시험을 하는 경우에는 장축 $(\mathrm{RD}$ 방향)과 수직 방향으로 배 열된다.

$\mathrm{RD}$ 방향으로 인장 시험이 진행 경우에 변형량에 따른 기공(blue circle)의 aspect ratio 변화를 보면 초기 1.39에 서부터 0.125 변형량에서 1.59 까지 $\mathrm{RD}$ 방향으로 연신되어 증가하는 것을 볼 수 있다. 그리고 이 이후의 변형이 진행 되면 strut 파괴가 발생하는 결과를 보였다. 반면 TD 방향 에서는 초기 기공의 aspect ratio가 0.6에서 시작되고 $\mathrm{RD}$ 방향 보다 높은 변형률인 0.28 에서 1.68 까지 증가한다. 이 후의 변형이 가해지면 파괴는 인장 방향의 약 $45^{\circ}$ 방향 (yellow arrows)으로 각각의 strut가 순차적으로 파괴되는 것으로 관찰되었다. Strut의 순차적인 파괴는 다공체 인장 시험의 방향에 관계없이 응력-변형률 곡선에서 최대 인장 강도 이후 응력의 계단식 감소 거동을 이해할 수 있는 중 요한 결과라고 판단된다. 또한 최대 연신율이 인장 시험 방향에 따라 다르게 나타나는 이유를 응력-변형률 곡선과 기공 형태 변화와 연계해서 해석을 해본다면 초기 기공의 aspect ratio가 낮은 경우에 strut가 인장 방향으로 배열(기 공 aspect ratio의 증가)되는데 더 많은 변형량이 필요함에 따라 연신율이 증가하는 것으로 이해될 수 있다.

이와 같이 인장 시험 방향과 기공의 배열은 연신율에도 영향을 줄 수 있지만 강도적인 측면에서도 특성을 변화시 킬 수 있다. 이러한 현상을 설명하기 위하여 그림 9에서는 기공의 배열과 인장 방향의 관계를 나타내는 개략도를 도 시하였다. 그림에서 나타낸 것과 같이 $\mathrm{RD}$ 방향으로 인장 이 되는 경우, 기공이 수직으로 배열되어 있고 하중을 지 
(a) Tensile direction

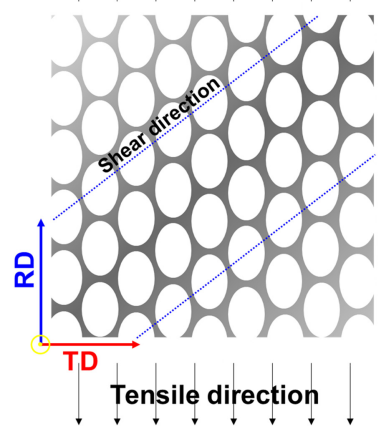

(b) $\uparrow$ Tensile direction

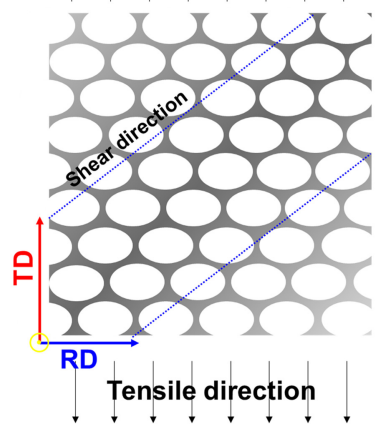

Fig. 9. Schematic diagram of the relationship between tensile direction and pore alignment; (a) RD direction and (b) TD direction.

탱할 수 있는 strut의 단위 면적당 개수(그림 9 (a))가 높 은 것을 알 수 있다. 반면 TD 방향으로 인장 시험이 진 행되는 경우, 기공의 배열이 인장 방향과 수직으로 배열된 단위 면적당 strut의 개수는 상대적으로 감소될 수밖에 없 다. 이와 함께 strut 개수 차이는 단위 면적당 strut의 연결 부위(node) 개수도 크게 변화시킬 수 있다. 이와 같은 방 향에 따른 구조적인 차이에 의하여 그림 6 에서 측정되었 던 것처럼 동일한 상대밀도를 가짐에도 방향에 따라 항복 및 최대 인장 강도가 다르게 나타나는 것으로 사료된다.

\section{4. 결 론}

본 연구에서는 분말 합금 공정을 통하여 Ni-Cr-Al 합금 다공체를 제조하였으며, 상온 인장 특성에 미치는 변형률 속도 및 인장 시험 방향에 대한 영향을 조사하여 다음과 같은 결과를 얻을 수 있었다.

(1) Ni-Cr-Al 다공체는 12면체 (dodecahedron)와 14면체 (tetrakaidecahedron)가 혼재된 Weaire-Phelan bubble 형태 로 관찰되었으며, 관찰 방향에 따른 기공 크기는 2762.4 $\mu \mathrm{m}$ (ND), $2709.1 \mu \mathrm{m}$ (RD), 그리고 $2518.4 \mu \mathrm{m}$ (TD)로 측정되었다. $\mathrm{Ni}-\mathrm{Cr}-\mathrm{Al}$ 다공체의 기공도(porosity)는 $97.07 \%$, 상대 밀도(relative density)는 $2.93 \%$ 으로 확인되 었다. Strut는 삼각형 파이프 형태, 평균 두께는 341.0 $\mu \mathrm{m}$, 평균 cell 벽면 두께는 $27.6 \mu \mathrm{m}$ 로 각각 측정되었으며, $\mathrm{Ni}$ 기지와 $\gamma^{\prime}$ 상으로 구성되어 있었다.

(2) $\mathrm{RD}$ 방향으로 인장 시험을 수행한 경우, 변형률 속도 에 따라서 $1.07 \mathrm{MPa}\left(10^{-2} / \mathrm{s}\right), 0.94 \mathrm{MPa}\left(10^{-3} / \mathrm{s}\right)$, 그리고 $0.84 \mathrm{MPa}\left(10^{-3} / \mathrm{s}\right)$ 의 항복강도를 가지는 것으로 측정되었으 며, 인장강도의 경우에도 $2.01 \mathrm{MPa}\left(10^{-2} / \mathrm{s}\right), 1.87 \mathrm{MPa}$ $\left(10^{-3} / \mathrm{s}\right), 1.84 \mathrm{MPa}\left(10^{-4} / \mathrm{s}\right)$, 연신율은 변형률 속도에 관계

없이 약 $17 \sim 22 \%$ 의 범위를 가지는 것으로 확인되었다. $\mathrm{TD}$ 방향의 항복강도는 각각 $0.65 \mathrm{MPa}\left(10^{-2} / \mathrm{s}\right), 0.54$ $\mathrm{MPa}\left(10^{-3} / \mathrm{s}\right), 0.52 \mathrm{MPa}\left(10^{-4} / \mathrm{s}\right)$, 인장강도는 $1.27 \mathrm{MPa}$ $\left(10^{-2} / \mathrm{s}\right), 1.20 \mathrm{MPa}\left(10^{-3} / \mathrm{s}\right)$, 그리고 $1.20 \mathrm{MPa}\left(10^{-4} / \mathrm{s}\right)$, 연신율은 약 $30 ~ 36 \%$ 의 범위로 측정되어 방향에 따라서 상이한 기계적 특성을 나타냈다.

(3) 방향에 따른 기계적 특성의 차이는 응력 방향, 기공 의 배열과 관계가 있다. $\mathrm{RD}$ 방향으로 인장이 되는 경우, 기공의 장축이 평행하게 배열되어 하중을 지탱할 수 있는 strut의 단위 면적당 개수가 증가함에 따라 상대적으로 높 은 항복강도 및 인장강도를 나타내는 것으로 사료된다. 반 면 초기 기공의 aspect ratio가 낮은 경우(TD 방향으로 인 장)에 strut가 인장 방향으로 배열(기공 aspect ratio의 증 가)되는데 더 많은 변형량이 필요함에 따라 연신율이 증가 하는 것으로 이해될 수 있었다.

\section{ACKNOWLEDGEMENT}

본 연구는 산업통상자원부의 전략적핵심소재 기술개발 사업의 연구비 지원으로 수행되었으며 이에 감사드립니다.

\section{REFERENCES}

1. L. J. Gibson and M. F. Ashby, Cellular solids: Structure and Properties, $2^{\text {nd }}$ Ed., p.96, Cambridge University Press, UK (1997).

2. T. J. Lu, H.A. Stone, and M.F. Ashby, Acta Mater. 46, 3619 (1998).

3. T. J. Lu, Int. J. Heat Mass Transfer. 42, 2031 (1999).

4. J. Banhart, Prog. Mater. Sci. 46, 559 (2001).

5. G. J. Davies and S. Zhen, J. Mater. Sci. 18, 1899 (1983).

6. D. T. Queheillalt, Y. Katsumura, and H. N. G. Wadley, J. Mater. Res. 16, 1028 (2001).

7. Q. Pang, G. H. Wu, Z. Y. Xiu, G. Q. Chen, and D. L. Sun, Mater. Sci. Eng. A 534, 699 (2012).

8. D. T. Queheillalt, Y. Katsumura, and H. N. G. Wadley, Scr. Mater. 50, 313 (2004).

9. Y. Boonyongmaneerat and D. C. Dunand, Adv. Eng. Mater. 10, 379 (2008).

10. S. Ochiai, S. Nakano, Y. Fukazawa, M.S. Aly, H. Okuda, K. Kato, T. Isobe, K. Kita, and K. Honma, Mater. Trans. 5, 925 (2010).

11. O. Smorygo, V. Mikutski, A. Leonov, A. Marukovich, and Y. Vialiuha, Scr. Mater. 58, 910 (2008).

12. K. A. Khor, L. G. Yu, O. Andersen, and G. Stephani, Mater. 
Sci. Eng. A, 356, 130 (2003).

13. H. Choe and D.C. Dunand, Acta Mater. 52, 1283 (2004).

14. Q. Pang, G. H. Wu, Z. Y. Xiu, L. T. Jiang, and D. L. Sun, Mater. Charact. 70, 125 (2012).

15. Q. Pang, Z. Y. Xiu, G. H. Wu, L. T. Jiang, D. L. Sun, and Z. L. Hu, J. Mater, Process. Technol. 212, 2219 (2012).

16. Y. J. Yi, M. J. Lee, J. Y. Yun, and B. K. Kim, Met. Mater. Int. 25, 1272 (2019).

17. D. Jung and Y. Kwon, Korean J. Met. Mater. 57, 747 (2019).
18. K. S. Kim, J. Y. Yun, B. G. Choi, and K. A. Lee, Met. Mater. Int. 20, 507 (2014).

19. J. S. Oh, M. C. Shim, M. H. Park, and K. A. Lee, Met. Mater. Int. 20, 915 (2014).

20. O.B. Olurin, N.A. Fleck, and M.F. Ashby, Mater. Sci. Eng. A 291, 136 (2000).

21. A. Paul and U. Ramamurty, Mater. Sci. Eng. A, 281, 1 (2000).

22. J. Choi and K. Kim, J. Kor. Powd. Met. Inst. 17, 489 (2010). 